\title{
成層地盤における正規モード解及びグリーン関数の効率的な計算法 EFFICIENT METHODS FOR COMPUTING GREEN'S FUNCTIONS AND NORMAL MODE SOLUTIONS FOR LAYERED HALF-SPACES
}

\author{
久田嘉章* \\ Yoshiaki HISADA
}

Several techniques for efficiently computing Green's functions and normal mode solutions for layered half-spaces are proposed. First, the reflection/transmision (R/T) matrix method is applied to computing normal mode solutions in order to obtain numerically stable results up to very high frequencies. Second, the phase velocities obtained from above and Filon's quadrature are used for the wavenumber integration of Green's functions; this method greatly reduces the number of total integration points. Finally, the cubic-spline interpolation is used to spacially interpolate Green's function, greatly reducing computational time to obtain many Green's functions. The validity of the methods are checked by comparing results using other methods.

Keywords: Green's function, normal mode solution, layered-half space, R/T matrix method, Filon's quadrature, Green function library, cubic-spline interpolation

グリーン関数、正規モード解、成層地盤、透過反射マトリックス法、

フィロンの数值積分法、グリーン関数ライブラリー、スプライン補間法

1.はじめに

成層地盤の正規モ一ド解及び動的グリーン関数を効率的に計算 することは、地震学・地震工学のみならず環境振動問題など建築・ 土木の分野でも重要である。特に近年、地震学・地震工学では震 源過程のインバージョンや面的な強震動波形のシミュレーションに 効率よく大量にグリーン関数を計算する必要に迫られている（例 えば文献 $\left.{ }^{11}\right)$ 。成層地盤の動的グリーン関数は境界要素法などの数 值解析法にも適用されて㧈り、その際には精度の高く数值的に安定 した解が要求されるう。

著者はこれまで、成層地盤に挰けるグリーン関数を数値的に安

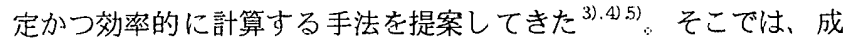
層を表記する伝達マトリックスにLuco and Apsel0 反射，“透過マ トリックス法（R/T Matrix法） 尚を改良し、高振動数までの数值安 定性を保証するとともに、振源の深さと観測点の深さが近いときに 生ずる数值不安定の問題も、波数積分に解析的な漸近解を導入し 解決した。

本論文では著者の方法を更に発展させ、R/T Matrix法を用いて 正規モード解を効率的に計算する方法、グリーン関数の波数積分を
高速化する方法、さらに多くの数のグリーン関数をライブラリー 值と補間法を組み合わせて計算する方法を提案する。な㧍、ここで 示されるフォートランによるブログラムはインターネットを通じ研 究目的に公開されている。

\section{2. 定式}

本論文で使われる成層地盤のグリーン関数の基本的な定式は文 献 ${ }^{3)}$ を、振源と観測点の深さが近い場合の解析的な処理法に関して は文献をを、参照されたい。以下の 2.1 ではそれらの要点の及記 し、2．2 で正規モード解への適用、2．3と2.4 で波数積分 法の効率化について、2．5 で膨大な数のグリーン関数を計算す る諸方法について述べる。

\section{$2.1 R / T$ Matrix法と振源と観測点の深さ が近い場合の処理}

成層地盤を表記する伝達マトリックスにはThomson-Haskel法 が多用されているが、この方法には高振動数で指数関数が発散し、 数値不安定になるという久点がある。このため、Haskell法を改良 
または全く別な定式による多くの手法が提案され、応用されている

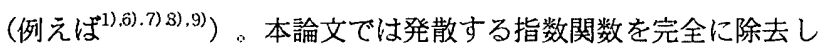
た反射・透過マトリックス法 (reflection / transmission matrix, $\mathrm{R} / \mathrm{T}$ Matrix法）を用いている。その記述法に関してはKennett ${ }^{7)}$ Luco and Apsel ${ }^{6)}$ の 2 つの方法があるが、ここではLuco and Apsel の方法を採用している。但し、原論文では振源を記述する項 に発散する指数関数が残っているため、ここではHarkrider ${ }^{10)}$ Kennettら がが行ったように振源の深さに仮想の層境界を設け、そ こにステップ応力条件を導入してその問題を解決している ${ }^{3)}$ 。

一方、グリーン関数を計算する際、振源と観測点の深さが同じ か近い場合は、波数積分の被積分関数が波数とともに発散してしま う。このため何らかの対策が必要になるが、被積分関数の漸近解 を導入し収束を早める方法 ${ }^{11), 12)}$ 、振動する被積分関数の極小・極 大值の平均值から近似解を求める方法 ${ }^{13)}$ 、積分路を複素積分路に 拡大して収束する被積分関数に変換する方法 ${ }^{14)}$ 、などが提案され ている。それぞれの手法には一長一短があるが (例えば文献 ${ }^{3) .51}$ )、 本論文では被積分関数に漸近解を導入する方法を採用している。そ の中でも多用されている方法は、波数が増大する（振動数が $0 に$ 近 づく）とグリーン関数が振源層と同じ物性の一様全無限体の静的 解に漸近する性質を利用するものである。すなわち、その漸近解を 被積分関数から引いて、被積分関数の収束を保証してから数値積 分を行い、次にその積分値に漸近解の解析積分値を加えて最終的な 解を求める方法である ${ }^{11), 12)}$ 。但し、この方法では振源が、自由表 面や層境界に近い場合、境界上にある場合、または観測点が振源之 は違う層にある場合などは、層境界から振幅の大きな反射波や透 過波が生じるため、一様全無限体の静的解の収束性は悪くなる。そ こで本研究では波数が大きい場合の反射・透過波を含む漸近解を 解析的に求め、それを用いている4)。

\section{2 反射・透過マトリックス法による 正規モード解の計算}

Ken nett法による反射・透過マトリックス法による表面波の分 散曲線やモード形、正規モード解などの計算法は文献 ${ }^{15)}$ などに示 されているが、ここではChen ${ }^{16)} に$ 習い、R/T法によるHisada ${ }^{3)}$ の 記述による定式を行う。

初めに表面波の特性方程式を導く。Hisada ${ }^{3)}$ の(A-1)式を用いる と、自由表面で応力0の条件からLove波・Ray eigh波ともに次式 を得る。

$$
\left\{\mathbb{E}_{21}^{1}+\mathbb{E}_{22}^{1} \Lambda_{\mathrm{u}}^{1}(0) \hat{\mathbb{R}}_{\mathrm{d}}^{(1)}\right\} \mathbb{C}_{\mathrm{d}}^{1}=0,
$$

記号の詳細はHisad ${ }^{3)}$ を参照されたい。上式のC $\mathrm{C}_{\mathrm{d}}^{1}$ は、第一層内で の下方に向かう波動の振幅を表すが、これが存在するためには上式 の中カッコ内の固有值が0 でなければならない。無次元化を行う と、Love波に対しては

$$
\frac{\operatorname{det}\left\{E_{21}^{1}+E_{22}^{1} \Lambda_{u}^{1}(0) \hat{R}_{d}^{(1)}\right\}}{\mu_{1} v_{\beta}^{1}}=0 .
$$

Rayleigh波に対しては

$$
\frac{\operatorname{det}\left\{E_{21}^{1}+E_{22}^{1} \Lambda_{u}^{1}(0) \hat{R}_{d}^{(1)}\right\}}{\left(\mu_{1}\right)^{2} v_{\alpha}^{1} v_{\beta}^{1}}=0 .
$$

を得る。ここで $\mu_{1}$ は第一層の剪断弾性係数であり、また、 $v_{\alpha}^{1}$ と $v_{\beta}^{1}$ はHisada ${ }^{3)}$ にされているように、

$$
\begin{array}{ll}
\left(v_{\alpha}^{1}\right)^{2}=\mathrm{k}^{2}-\left(\omega_{\alpha^{1}}\right)^{2}, & \operatorname{Re}\left(v_{\alpha}^{1}\right) \geq 0 \\
\left(v_{\beta}^{1}\right)^{2}=\mathrm{k}^{2}-\left(\omega_{\beta^{1}}\right)^{2}, & \operatorname{Re}\left(v_{\beta}^{1}\right) \geq 0 .
\end{array}
$$

である。 $V_{\alpha}^{1} と V_{\beta}^{1}$ は、第一層のP波・S 波速度に該当する分岐点で 0となるが、(2)、(3)式の分子も同じ分岐点で0となり、これを相 殺するために上式には導入している。さらに分子が波数とともに振 幅が増大して発散するのを防ぐ目的もある。

(2)、（3)式が表面波の存在条件を決める特性方程式であり、周期 ごとに各モードの固有值（位相速度）が決定される。一方、深さ方 向の振幅分布である固有ベクトル、及び群速度は以下のように計 算される。まず固有変位ベクトルはHisada ${ }^{3)}$ の(A-1)式左辺のDよ り、固有応力ベクトルは同じくSょり、容易に計算される。一方、 群速度は求められた固有ベクトルを深さ方向にエネルギー積分を 求め、文献 ${ }^{17)} の(7.70)$ 式で計算する。この方法は、各層ごとに固有 ベクトルが解析的に積分でき、効率的に群速度が計算される。また 微分ではなく積分を用いるため数值的に安定している利点もある。

\section{3 グリーン関数の効率的な波数積分法 (その 1 : 極の扱い)}

グリーン関数を波数積分して求める際、二つの点に注意しなけ ればならない。まずは被積分関数が表面波の位相速度に相当する波 数（極）で発散することである。通常、層構造の速度に虚数を導 入して減衰を表すため発散は無くなる。しかし減衰が小さな場合は 鋭いビーク值を示すため特別な配慮が必要になる。

これに対処するために良く用いられるのはPhinneyによる方法 18)である。これは振動数に仮想の虚数 $\left(\varpi_{I}\right)$ を導入し、被積分関 数をなだらかな関数にして波数積分し、時間領域に戻す際に $\exp \left(\varpi_{\mathrm{I}} \mathrm{\imath}\right)$ を掛けて仮想減衰による減少分をもとに戻す方法であ る。この方法は非常に簡便であるが、後の計算例に示すように時間 領域でexp $\left(\bar{\omega}_{\mathrm{I}} \mathrm{t}\right)$ を掛けた際、数值誤差の蓄積で波形の尾部の精 度が悪化する場合があるので注意を要する。

本研究では、2.2 で計算した表面波の位相速度を利用する。す なわちグリーン関数に先だって位相速度を計算し、各モードの極の 位置を調べて㧍き、積分する際に極回りで密な積分点を配置する 方法である。この方法では全継続時間で精度良い解が得られる。し かし、構造の減衰が非常に小さい場合には、極回りの積分評価に はCauchyの主值などによる䈯密な評価をしないと、精度が悪くな る可能性があることに注意を要する。

\section{4 グリーン関数の効率的な波数積分法 (その 2 : 波数が大きい場合)}

ゲリーン関数を波数積分して求める際の二つめの問題は、振源 と観測点の水平距離と波数の積が大きい場合、被積分関数が激しく 振動し、数值積分が困難になることである。このような関数を効 率的に積分する方法が各種提案されている ${ }^{13) .14)}$ 。本研究では、被 積分関数は調和関数に収束することを利用し、Fibnの積分法を採 用する。これ梳、ある小さな積分区間ごとに調和関数の包絡線を高 次関数で近似し、その高次関数と調和関数との積を解析的に積分 
寸る方法である。必要な積分点は、調和振動する包絡形状のみであ るため、通常の積分法に比べて積分点数を著しく減らせる。包絡線 を 1 次近似した方法は文献”などによって用いられているが、ここ ではより精度の高い二次近似式を用いる。

グリーン関数に必要な波数積分は次式でまとめられる。

$$
\begin{aligned}
& \int_{0}^{\infty} \mathrm{f}(\mathrm{k}, \mathrm{r}) \mathrm{J}(\mathrm{kr}) \mathrm{dk}= \\
& \int_{0}^{\mathrm{k} 0} \mathrm{f}(\mathrm{k}, \mathrm{r}) \mathrm{J}(\mathrm{kr}) \mathrm{dk}+\int_{\mathrm{k} 0}^{\infty} \mathrm{f}(\mathrm{k}, \mathrm{r}) \mathrm{J}(\mathrm{kr}) \mathrm{dk}
\end{aligned}
$$

ここで、 $\mathrm{J}$ はベッセル関数、 $\mathrm{k}$ は波数、 $\mathrm{r}$ は振源から観測点までの 水平距離である。上式右辺で、 $\mathrm{kr}$ （波数×水平距離）が 3 程度より 小さい場合、すなわち第 1 項の数值積分にはSimpson法を用いる。

一方、第二項にはFibnの積分を用いる。 $\mathrm{k}_{0} \times \mathrm{r}$ の值が 3 程度以 上とすると、ベッセル関数は以下の式で非常に精度良く近似される (例えば文献 ${ }^{19)}$ )。

$J_{0}(\mathrm{kr}) \approx \frac{1}{\sqrt{\pi \mathrm{kr}}}\left\{\cos (\mathrm{kr})\left(1-\frac{1}{8 \mathrm{kr}}\right)+\sin (\mathrm{kr})\left(1+\frac{1}{8 \mathrm{kr}}\right)\right\}$

$\mathrm{J}_{1}(\mathrm{kr}) \approx \frac{1}{\sqrt{\pi \mathrm{kr}}}\left\{\sin (\mathrm{kr})\left(1+\frac{3}{8 \mathrm{kr}}\right)-\cos (\mathrm{kr})\left(1-\frac{3}{8 \mathrm{kr}}\right)\right\}$

(6)式を(5)式に代入し、 $\sin$ 項と $\cos$ 項で整理すると(5)式の第二項は 以下の二つの式にまとめられる。

$$
\begin{aligned}
& \int_{\mathrm{k} 0}^{\mathrm{k} 2 \mathrm{n}} \mathrm{f}^{\mathrm{C}}(\mathrm{k}, \mathrm{r}) \cos (\mathrm{kr}) \mathrm{dk} \text { 及び } \\
& \int_{\mathrm{k} 0}^{\mathrm{k} 2 \mathrm{n}} \mathrm{f}^{\mathrm{S}}(\mathrm{k}, \mathrm{r}) \sin (\mathrm{kr}) \mathrm{dk}
\end{aligned}
$$

本研究では被積分関数の収束性はどのような条件下でも 2.1 によっ て保証されているため、積分範囲の上限を $\mathrm{k}_{2 \mathrm{n}}$ で打ち切っている。

$\mathrm{k}_{0}$ から $\mathrm{k}_{2 \mathrm{n}}$ までの積分範囲を間隔 $\Delta \mathrm{k}$ で $2 \mathrm{n}$ 個に分割し、小さい 方から波数を $\mathrm{k}_{0}, \mathrm{k}_{1}, \mathrm{k}_{2}, \ldots . . \mathrm{k}_{2 \mathrm{n}}$ とする。この時、2次の Filon積分法を用いると(7)式は以下のように表現できる ${ }^{20\}}$ 。

$$
\begin{aligned}
& \int_{\mathrm{k} 0}^{\mathrm{k} 2 \mathrm{n}} \mathrm{f}^{\mathrm{C}}(\mathrm{k}, \mathrm{r}) \cos (\mathrm{kr}) \mathrm{dk} \approx \Delta \mathrm{k}\left[\alpha ( \mathrm { hr } ) \left\{\mathrm{f}_{2 \mathrm{n}}^{\mathrm{C}} \sin \left(\mathrm{rk}_{2 \mathrm{n}}\right)\right.\right. \\
& \left.\left.-\mathrm{f}_{0}^{\mathrm{C}} \sin \left(\mathrm{rk}_{0}\right)\right\}+\beta(\mathrm{hr}) \mathrm{C}_{2 \mathrm{n}}+\gamma(\mathrm{hr}) \mathrm{C}_{2 \mathrm{n}-1}\right] \\
& \int_{\mathrm{k} 0}^{\mathrm{k} 2 \mathrm{n}} \mathrm{f}^{\mathrm{s}}(\mathrm{k}, \mathrm{r}) \operatorname{sins}(\mathrm{kr}) \mathrm{dk} \approx \Delta \mathrm{k}\left[\alpha ( \mathrm { hr } ) \left\{\mathrm{f}_{0}^{\mathrm{s}} \cos \left(\mathrm{rk}_{0}\right)\right.\right. \\
& \left.\left.-\mathrm{f}_{2 \mathrm{n}}^{\mathrm{S}} \cos \left(\mathrm{rk}_{2 \mathrm{n}}\right)\right\}+\beta(\mathrm{hr}) \mathrm{S}_{2 \mathrm{n}}+\gamma(\mathrm{hr}) \mathrm{S}_{2 \mathrm{n}-1}\right] \\
& \text { ここで、 } \\
& \mathrm{f}_{\mathrm{i}}^{\mathrm{C}}=\mathrm{f}^{\mathrm{C}}\left(\mathrm{k}_{\mathrm{i}}, \mathrm{r}\right), \mathrm{f}_{\mathrm{i}}^{\mathrm{S}}=\mathrm{f}^{\mathrm{S}}\left(\mathrm{k}_{\mathrm{i}}, \mathrm{r}\right), \quad(\mathrm{i}=0,1,2, \ldots 2 \mathrm{n}) \\
& \alpha(\mathrm{x})=\frac{1}{\mathrm{x}}+\frac{\sin 2 \mathrm{x}}{2 \mathrm{x}^{2}}-\frac{2 \sin ^{2} \mathrm{x}}{\mathrm{x}^{3}} \text {. } \\
& \beta(x)=2\left(\frac{1+\cos ^{2} x}{x^{2}}-\frac{\sin 2 x}{x^{3}}\right) \text {. }
\end{aligned}
$$

$$
\gamma(\mathrm{x})=4\left(\frac{\sin \mathrm{x}}{\mathrm{x}^{3}}-\frac{\cos \mathrm{x}}{\mathrm{x}^{2}}\right)
$$

$\mathrm{C}_{2 \mathrm{n}}=\sum_{\mathrm{i}=1}^{\mathrm{n}} \mathrm{f}_{2 \mathrm{i}}^{\mathrm{C}} \cos \mathrm{rk}_{2 \mathrm{i}}+\frac{1}{2}\left\{\mathrm{f}_{0}^{\mathrm{C}} \cos \mathrm{rk}_{0}-\mathrm{f}_{2 \mathrm{n}}^{\mathrm{C}} \cos \mathrm{rk}_{2 \mathrm{n}}\right\}$

$\mathrm{S}_{2 \mathrm{n}}=\sum_{\mathrm{i}=1}^{\mathrm{n}} \mathrm{f}_{2 \mathrm{i}}^{\mathrm{s}} \sin \mathrm{rk}_{2 \mathrm{i}}+\frac{1}{2}\left\{\mathrm{f}_{0}^{\mathrm{s}} \sin \mathrm{rk}_{0}-\mathrm{f}_{2 \mathrm{n}}^{\mathrm{s}} \sin \mathrm{rk}_{2 \mathrm{n}}\right\}$

$$
\mathrm{C}_{2 \mathrm{n}-1}=\sum_{\mathrm{i}=1}^{\mathrm{n}} \mathrm{f}_{2 \mathrm{i}-1}^{\mathrm{C}} \cos \mathrm{rk}_{2 \mathrm{i}-1} \text {. }
$$$$
\mathrm{S}_{2 \mathrm{n}-1}=\sum_{i=1}^{\bar{\pi}} \mathrm{f}_{2 \mathrm{i}-1}^{\mathrm{s}} \sin \mathrm{rk}_{2 \mathrm{i}-1} \text {. }
$$

\section{5 膨大な数のグリーン関数を計算するため に有効な諸手法}

上に示した諸手法によってグリーン関数は、どのような条件下 でも高振動数まで高速に計算される。しかし多重震源モデルの震源 インバージョンを行う場合（例えば'211)，境界要素法の基本解に 用いる場合 (例えば”)，有限要素法や差分法への3次元入射場を 計算する場合、などには数千から数百万のグリーン関数の計算が必 要となることがある。この場合、以下に示さ扎る2つの手法が有 効である。

まず初めは、Hisada ${ }^{3)}(\mathrm{A}-1)$ 式で各層の下降・上昇波の振幅を 表す係数 $\mathrm{C}_{\mathrm{d}}^{\mathrm{j}}$ と $\mathrm{C}_{\mathrm{u}}^{\mathrm{j}}$ を、予めライブラリーとしてブログラムの中で 計算して抢く方法である。実際の波数積分は、このライブラリ一值 を用いて計算する。この方法は、 $\mathrm{C}_{\mathrm{d}}^{\mathrm{j}}$ と $\mathrm{C}_{\mathrm{u}}^{\mathrm{j}}$ の計算に最も演算時間 をとられること、この係数はある周波数では振源深さhと波数 $\mathrm{k} 0$ みの関数であり、観測点とは独立していること、などから、点振源 に対して観測点数がたくさんある場合に有効である。それに対して ダブルカップル震源の場合は、Hisada ${ }^{3)}$ の(22)式に示されるよう に相反定理を用いていないため、hが観測点深さとなり、逆に震源 の数がたくさんある場合に有効となる。

次の方法はグリーン関数ライブラリーと補間法を組み合わせて 用いる方法である（例えば ${ }^{21)}$ )。すなわち、予めある任意面の荒 いグリッド上に、笪密なグリーン関数のライブラリーを作成して扝 き、任意点のグリーン関数值はライブラリー值を補間して計算す る方法である。本研究では補間法としてculic-spline法 ${ }^{229}$ を用い ている。

\section{3. ソースプログラムの公開}

本論文で示された正規モード解、ゲリーン関数、補間法などの ソースブログラム（フォートラン）及びマニュアル等はインターネッ

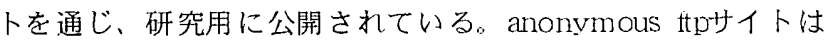
133.80.156.38で、ディレクトリーは pul/hisada である。最新情 報はそこのREADMEファイルを参照されたい。

\section{4. 計算結果及び考察}

以下の解析では、すべて表 1 に示す地殼モデルを用いて本諸 手法の妥当性の確認を行った。

\section{1 分散曲線と固有モードの計算}

図 1 に 2.2 に示した方法による表面波の位相速度と群速度の分 散曲線を示す。図2 は、1 HZ の時の特性関数で、のが位相速度に 
相当する。ここでは特性関数の絶対值（実線）を用いて、その振幅 が0になるところを位相速度としている。図に見られるように振動 数が大きくなると固有モードの数が増大し、特に各層の剪断波速度 より少し大きな所に近傍に集中する。従って位相速度を求めるア ルゴリズムには、この部分にはより細かな分割数を用いている。図 3 には $1 \mathrm{HZ}$ 時の深さ $50 \mathrm{~km}$ までの変位と応力のモード形を示 す。低次モ一ドでは表層付近に、高次になるほど哚い層まで振幅が 分布している。当然ながら、応力は地表面では 0 となる。

\section{2 グリーン関数の計算}

表 10 地盤モデルと表 2 に示す震源モデルと観測点位置を用い て、グリーン関数の計算を行う。表のX力向が北、Yが東に相当し、 振動数は $1 \mathrm{HZ}$ まで計算している。まず手法のチェックとして、 図 4 に観測点が地表面にある場合の本手法とSaikiaのブログラムを

用いた結果の比較を示す。Saikia ${ }^{9)}$ は Propagator Matrix として Haskell 法を改良した Compound Matrix 法を用い、波数積分法 はFrequency - Wavenumber 積分法之 1 次 Filon 法を組为合わ せて用いている。図4に示されるように両者の結果は非常に良く一 致している。但し、子細に見ると後続波形部分に少し位相のずれ

表 1 : 本研究で用いる地殼構造モデル

\begin{tabular}{|c|c|c|c|c|c|}
\hline 密度 $\left(\mathrm{g} / \mathrm{cm}^{3}\right)$ & P波速度 $(\mathrm{m} / \mathrm{sec})$ & $\mathrm{Qp}$ & S波速度 $(\mathrm{m} / \mathrm{sec})$ & $\mathrm{Qs}$ & 厚さ $(\mathrm{m})$ \\
\hline 2.50 & 3900.0 & 100.0 & 2200.0 & 50.0 & 2500.0 \\
\hline 2.60 & 5100.0 & 200.0 & 2700.0 & 100.0 & 1000.0 \\
\hline 2.70 & 6000.0 & 300.0 & 3500.0 & 150.0 & 12500.0 \\
\hline 2.90 & 6800.0 & 500.0 & 3800.0 & 250.0 & 16000.0 \\
\hline 3.10 & 7600.0 & 500.0 & 4250.0 & 250.0 & - \\
\hline
\end{tabular}

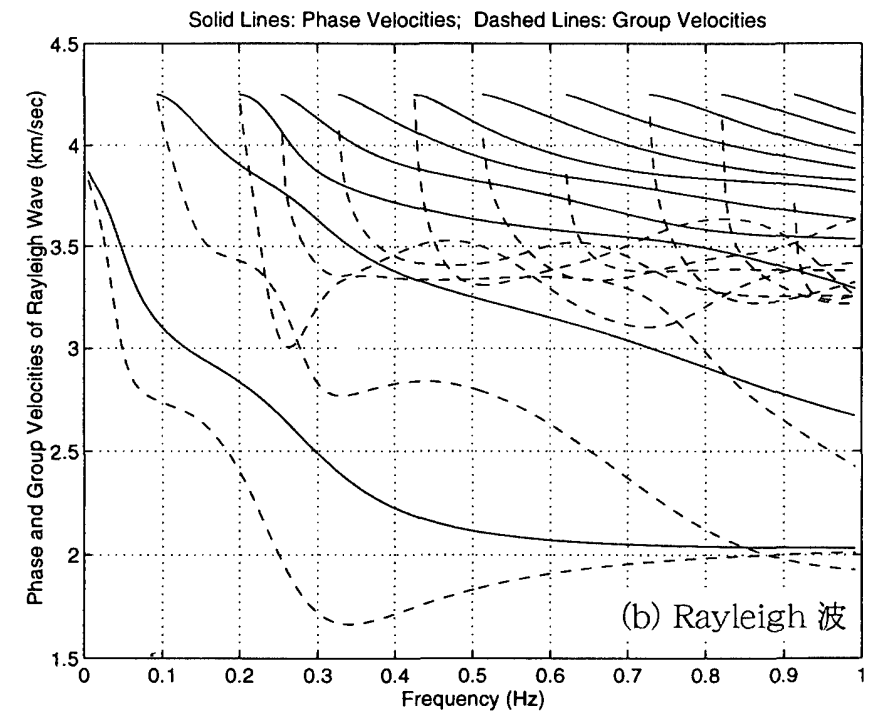

図 1 : Love波とRayleigh波の分散曲線（実線：位相速度、破線：群速度）
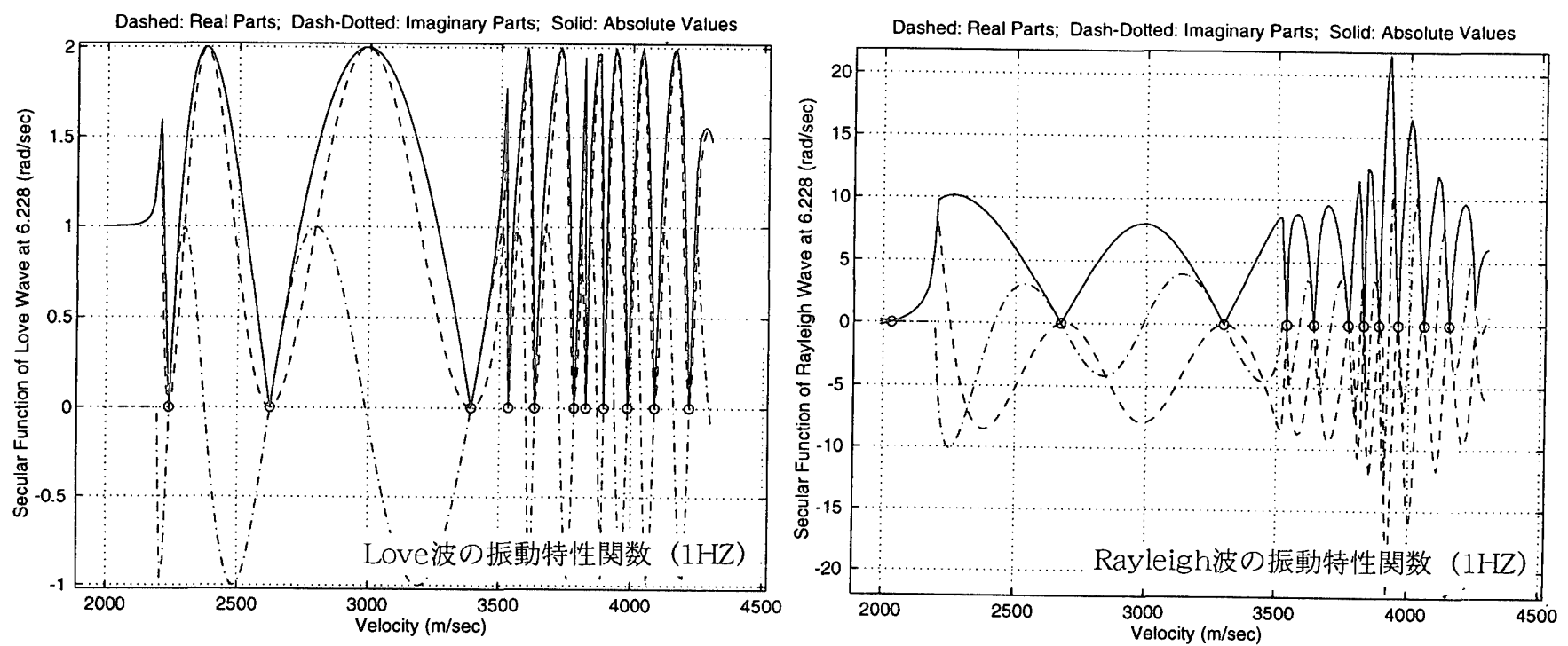

図 2 : 振動数が $1 \mathrm{HZ}$ 時の振動特性関数（実線：絶対値、破線 : 実数、一点鎖線 : 虚数、 $\bigcirc:$ 極) 

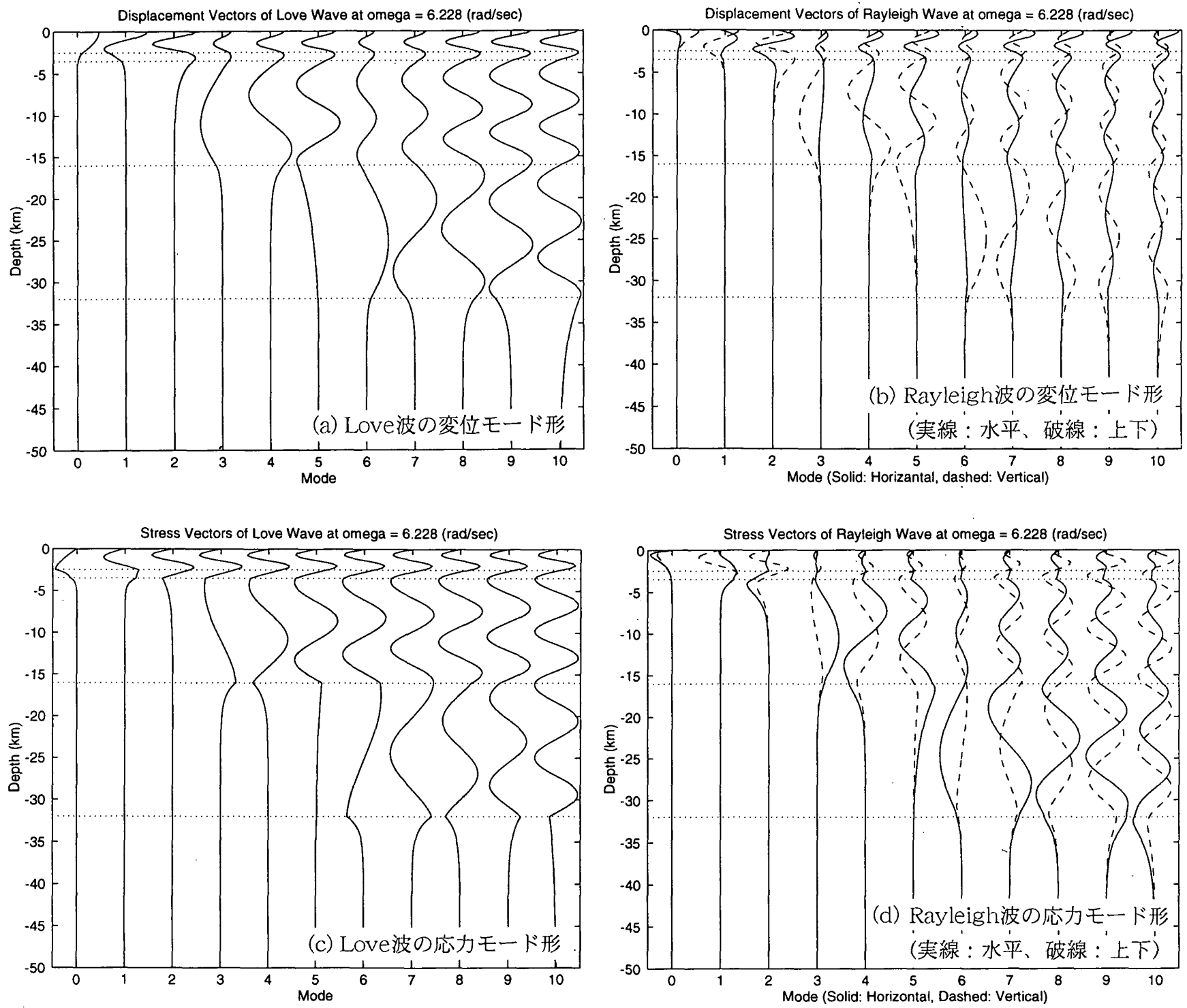

図 3: 振動数が1HZ時の各次の変位及び応力のモード形（図中、水平の破線は層の境界を示す）

表 $2:$ 本研究で用いる点震源モデルのバラメータ と観測点位置

\begin{tabular}{|c|c|c|c|}
\hline 震源位置 $(x, y, z: m)$ & 地震moment(dyne*cm) & strike角(度) & dip角(度) \\
\hline$(0,0,1000)$ & $5.0 \mathrm{e}+2.3$ & 220 & 50 \\
\hline
\end{tabular}

\begin{tabular}{|c|c|}
\hline rake角(度) & rise time(sec) \\
\hline 20 & 0.4 \\
\hline
\end{tabular}

\begin{tabular}{|l|l|}
\hline 観測点位置 $(x, y: m)$ & 観測点深 $(\mathrm{m})$ \\
\hline$(17430.0,-1992.39 .0)$ & 0,990, or 1010 \\
\hline
\end{tabular}

が見られ、またSaikiaの結果には波形の尾部のノイズが見える。こ れは 2.3 に述べたようにPhinney法 ${ }^{18}$ に起因すると考えられる。 因みに演算時間は、日立のワークステーション3050RXを用いて Saikiaでは波形を得るのに約20秒、本手法では約100秒であり、 Saikiaの方が 5 倍程度早い。すなわ計算時間に関しては Phinney法は積分点を大きく減らせるため有効である。

後続波の精度、及び観測点深さが震源深さにごく近い場合の精
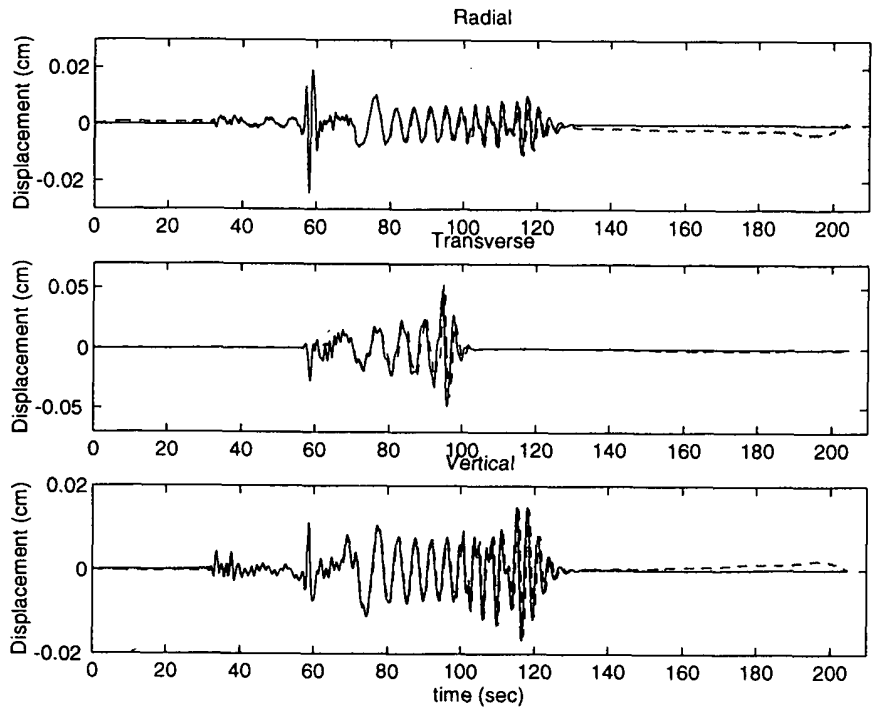

図 4 : 本手法によるグリーン関数（実線） とSaikiaによる関数 (破線) の比較 

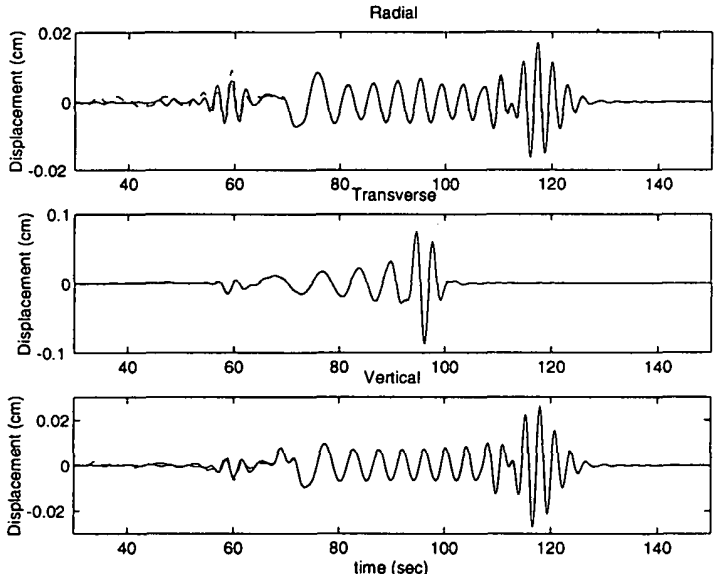

（a）観測点は地表面
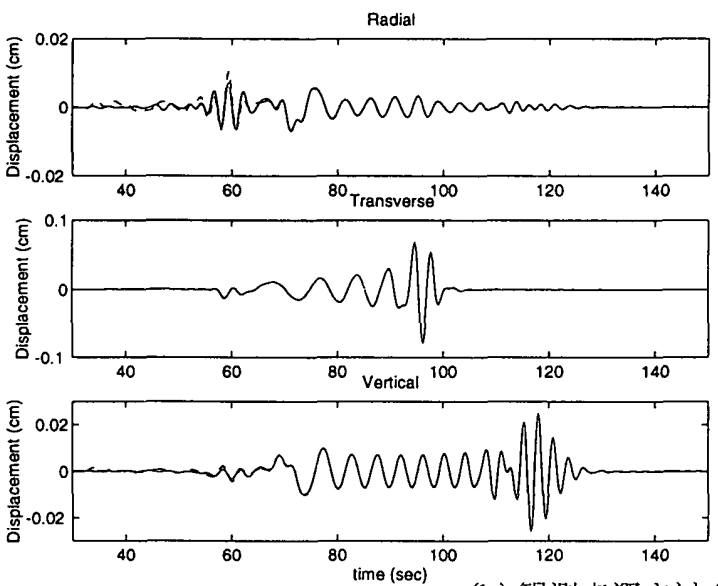

(b) 観測点深さは $990 \mathrm{~m}$
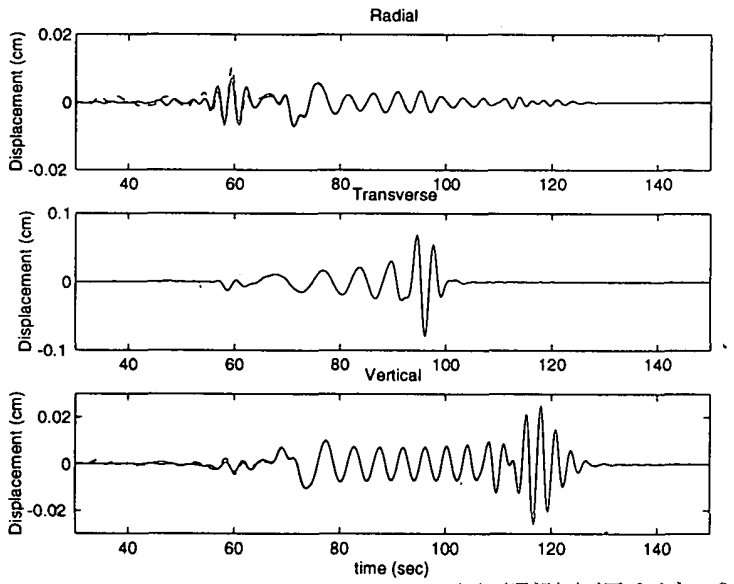

(c) 観測点深さは $1010 \mathrm{~m}$

図 5 : 本手法によるグリーン関数（実線）と

Harkriderによる正規モ一ド解（破線）の比較

度をチェックするため、Harkrider ${ }^{10)}$ のアルゴリズムで正規モード 解を計算して比較する。但し、HarkriderはHaskell 法を用いてお り、高振動数で解が数值的に発散してしまうため、振動数は0.488 $\mathrm{HZ}$ まで落としている。Q值は表 10 全層で100として、正規モ一 ド解には文献 ${ }^{17)} の$ (7.93)式を用いる。図 5 に本手法による結果と 正規モード解による結果を示す。このうち(し)と(c)は、観測点深さ
が震源深さの $1000 \mathrm{~m} に$ 比べ、10m浅い場合と深い場合である。どの 結果も、実体波に相当する初動部分を除き、両手法による結果は完 全に一致している．従って、本手法による結果の妥当性は実証さ れたと考えられる。

\section{3 グリーン関数ライブラリーとSpline補間に よるグリーン関数の空間的㭪間法}

2.5 で述べたように、cubic-spline法を用いてグリーン関数を 空間的に補間することを試みる。ここではライブラリーのベースと なるゲリーン関数のグリッド間隔が、よ゙の程度の波長間隔であれ ば、精度良く補間できるかを調べる。

図 6 に使用するモデルを示す。傾斜角が90度の $2.2 \mathrm{~km} \times 2.2 \mathrm{~km}$ の平面に矩形のグリッドを置き、皦密に計算したグリーン関数と spline補間による関数との比較を図 7 に示す。観測点は平面の対角 線上に採る。図 7 の破線は、最上層内で最小周期 1 秒の $1 . ’ 8$ 波長

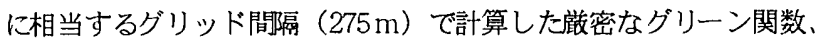
奏線はspline補間による関数である。図 7 (a)の実線は、 $2.2 \mathrm{~km}$ 間 隔グリッド（すなわち最上層内で最短周期 1 秒の 1 波長に相当し、 図で $\triangle 0$ 付いている場所）でグリーン関数を計算し、その間の 275 $\mathrm{m}$ 間隔の波形をspine補間した波形である。破線の厳密解と比べる と長周期の波は良く再現されているが、短周期波は全く再現されず、 最大振幅も過小に評価されている。次に図 7 (に)の実線は、 $1.1 \mathrm{k} \mathrm{m}$ 間隔グリッド（すなわち最小周期 1 秒の $1 / 2$ 波長に相当し、図で $\triangle$ の付いている場所）でグリーン関数を計算し、その間を補間した波 形である。図 7 (a)に比べ、補間波形は改善されて㧍り、実用上は この程度の荒いグリッド間隔でも支障はなさそうである。但し、子

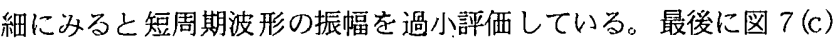
の実線は、 $0.55 \mathrm{~km}$ 間隔グリッド（すなわち最小周期 1 秒の $1 / 4$ 波 長に相当し、図で $\triangle 0$ 付いている場所）でグリーン関数を計算し、 その間を補間した波形である。破線の览密な波形と完全に一致して いることが分かる。すなわち、culic-spline補間を用いてグリー

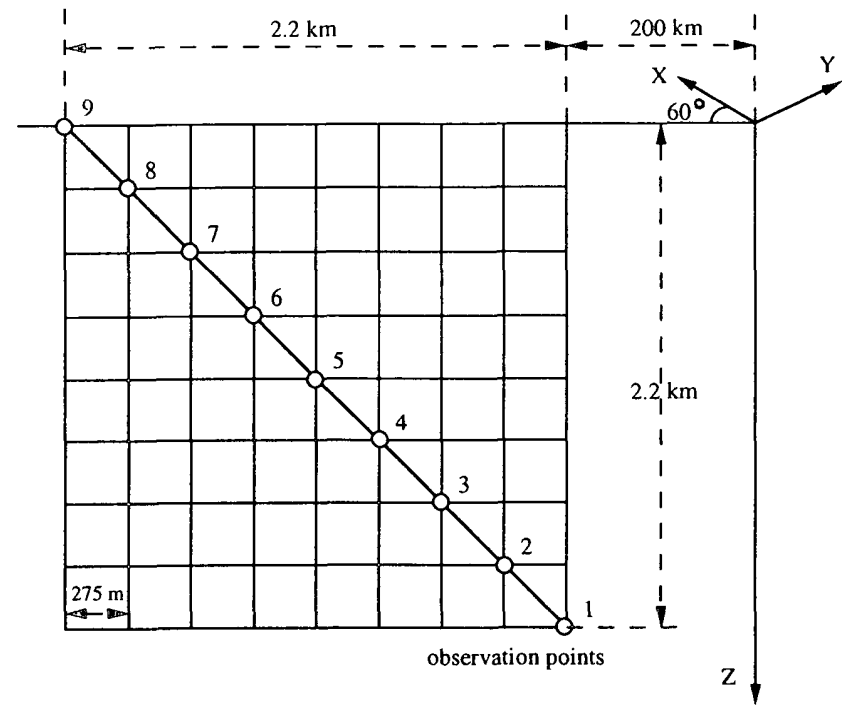

図 6 : Spline補間を用いたグリーン関数の補間を チェックするために用いる観測点位置 
NS

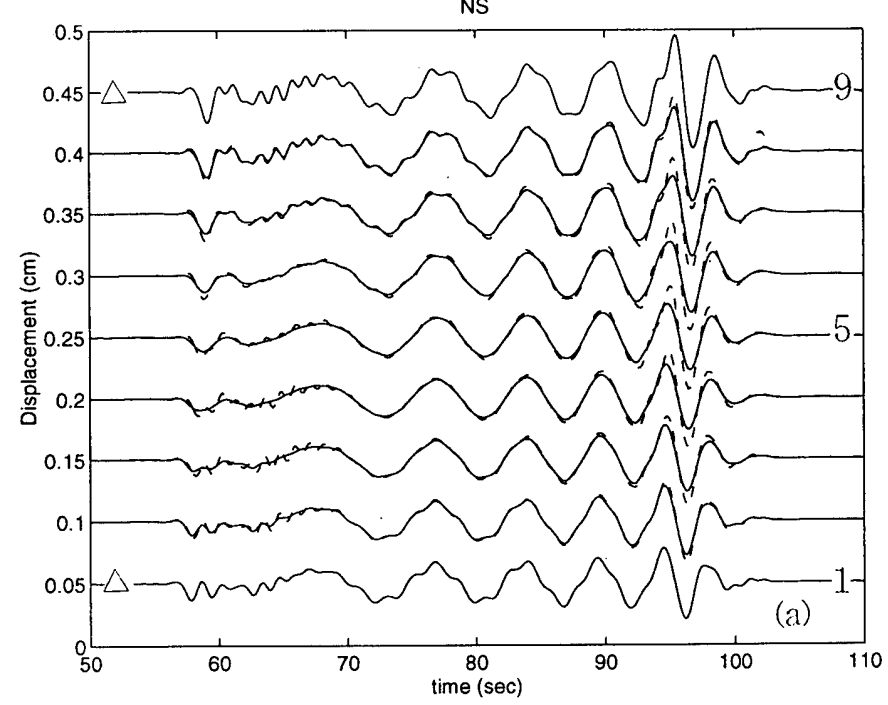

NS

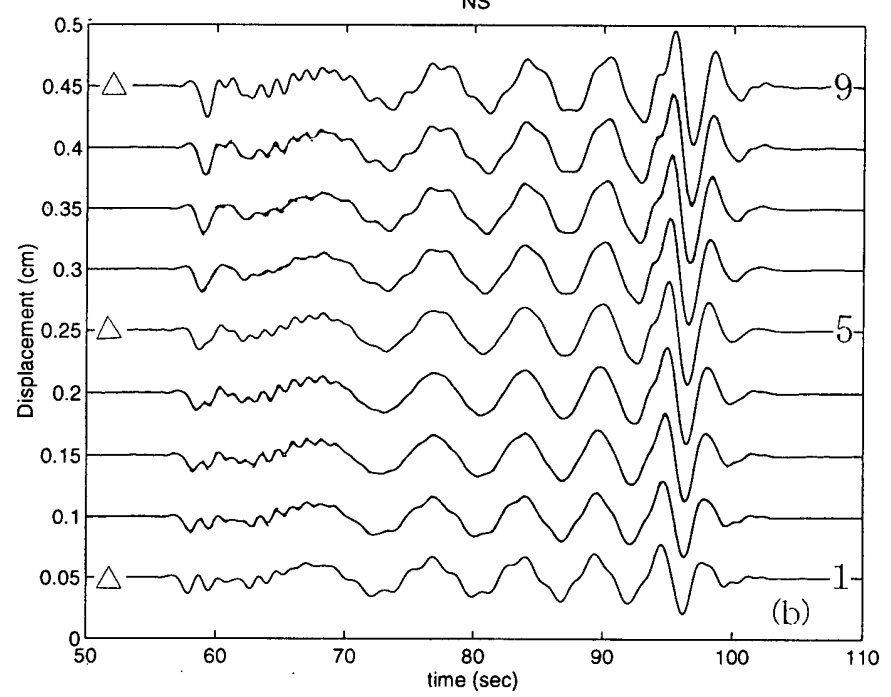

NS

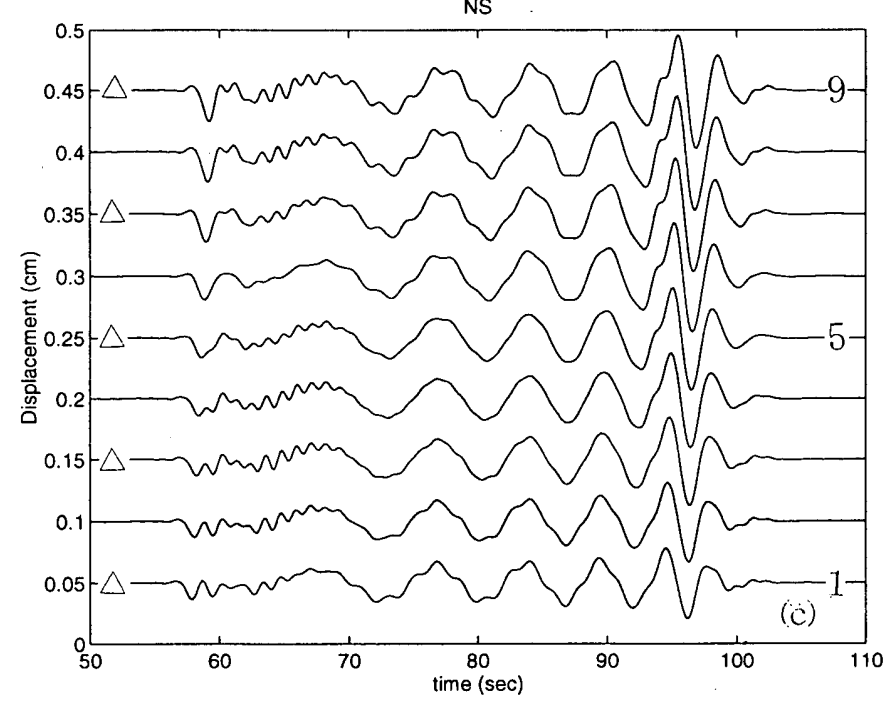

図 7 : Spline補間を用いたグリーン関数の補間のチェッグ (図中、破線は厳密なグリーン関数、実線は補間関数、 வはベースとなるグリーン関数の位置）
関数を補間して計算する場合、ベースとなるグリーン関数のグリッ ド間隔は、最小周期の1/4波長で充分である。

\section{5. 結論}

本論文では、成層地盤のゲリーン関数を計算するHisadaの方法 をさらに発展させ、正規モード解計算への応用、正規モ一ド解及び 高次 Filon 積分を利用した波数積分の高速化、大量のグリーン関数 を計算するためにcubic-spline法を用いた補間法、などを提案し、 その諸手法のチェックを行った。その結果、1）本手法がR/Tマト リックス法を用いているため、分散曲線やモード形なども高振動数 まで安定して計算すること、2) 観測点深さが震源深さに近い場合 にも、精度良いグリーン関数が計算されること、3）最小周期の 1/4波長のグリッド間隔でベースとなるグリーン関数を計算して㧍 けば、spIne補間によって精度良いグリーン関数が計算されること、 なジが明らかになった。また本研究で使用したソースコードは、研 究用にすべてインターネットにて公開した。

\section{謝辞}

$\mathrm{R} / \mathrm{T}$ マリックス法のグリーン関数と正規モ一ド解への応用は、 著者が南カルフォルニア大学に滞在中、X. Chen 氏（現、北京大 学) から助言を頂き、ブログラム化を行いました。C. Saikia 氏（ Woodward Clyde 社) にはダリーン関数計算のブログラム使用を 許可して頂き、使用に際しては佐藤俊明氏（清水建設）と供に助言 を頂きました。また吉田一博氏（清水建設）及び査読者には貴重 なご意見を頂きました。本研究の一部は、米国NSF（contract Num. ACS-9318163) \& Southern Califomia Earthquake Center (NSF Num. EAR - 8920136 and USGS Num. 14-08-0001-A 0899)、平成 8 年度文部省科研費奖励研究、及び 工学院大学総合研究所プロジェクト研究によって補助を頂きました。

\section{参考文献}

1) 䋶縝一起、竹中博士：総合報告：近地地震波の伝播に関する理 論、地震 2、Vol.42, pp.391-403, 1989

2) Hisada, Y., K. Aki and T.L. Teng : 3-D simulations of surface wave propagation in the Kanto sedimantary basin. Japan (Part 2: Application on the surface wave BEM), Bull. Seism. Soc. Am., Vol.83, No.6, pp.1700 - 1720. 1993.

3) Hisada, Y : An efficient method for computing Green's functions for a layered half-space with sources and receivers at close depths. Bull Seism. Soc. Am. Vol.84, pp. $1456-1472.1993$.

4) Hisada, Y : An efficient method for computing Green's functions for a layered half-space with sources and receivers at close depths (Part 2), Bul. Seism. Soc. Am., Vol.85, pp.1080-1093, 1995

5) Hisada, Y. : Reply to comments on "An efficient method for computing Green's functions for a layered half-space with sources and receivers at close depths" ty Roy J. Greenfield, Bull. Seism. Soc. Am., Vol85, No.5, pp.1525-1526. 1995. 
6) Luco. J. E. and R. J. Apsel (1983). On the Green's functions for a layered halt-space. Part 1. Bull Seism. Soc. Am., Vol.73, pp.909-929, 1983.

7) Kennett, B. L. N. and N. J. Kerry. : Seismic waves in a stratified half space, Geophys. J. R. astr. Soc., Vol.57, pp.557-583, 1979.

8) 源栄正人、菅原長、永野正行: 3 次元成層地盤に抢けるMoving Green's Functionの基本的倹討、日本建築学会構造系論文集、

第462号、pp.51-60, 1994

9) Saikia, C. K. : Modified frequency-wavenumber algorithm for regional seismograms using Filon's quadrature: modeling of Lg waves in eastern North America, Geophys. J. Int., Vol.118, pp.142-158, 1994.

10) Harkrider, D. G. : Surtace waves in multilayered elastic media; Rayleigh and Love waves from kuried sources in a multilayered ehstic halt-space, Bull. Seism. Soc. Am., Vol.54, pp.627-679, 1964

11）野島治、田治見弘、市川修三: 建物と地盤との動的相互作用 に関する研究、竹中工務店技術研究所、第 9 号、pp. 38-51, 1973.

12) Apsel R. J. and J. E. Luco. On the Green's tunctions for a hyered halt-space. Part 2, Bull. Seism. Soc. Am.. 73. 931-951, 1983.

13) Chang, S: Complete wavefield modeling and seismic inversion for lossy-eastic layered halt-space due to surface force. Doctor of Philosophy, University of Southern California, 1988.

14) Greenfield, R.J. : Comments on "An efficient method tor computing Green's functions for a layered half-space with sources and receivers at close depth" ky Y. Hisada, Bul. Seism. Soc. Am., Vol.85, No.5, pp.1523-1524, 1995.

15) Kerry, N.L.: Synthesis of seismic surface wave, Geophys. J. R. astr. Soc., Vol.33, pp.983-993, 1981.

16) Chen, X.: A systematic and efficient method of computing normal modes for multilayered half-space. Geophys. J. Intrn., Vol.115, pp.391-409, 1993.

17) Aki. K. and P. G. Richards: Quantitative Seismology, Theory and Methods. Vol. 1, W. H. Freeman and Company, 1980.

18) Phinney, R.A. : Theoretical calculation of the spectrum of first arrivals in layered elastic media, J. Geophys. Res., Vol.70, pp.5107-5123, 1965.

19）森口繁一、宇田川桂久、一松 信 : 数学公式 3（特殊関数）、岩 波全書、1959

20) Atramowitz M. and I. A. Stegun: Handkook of Mathematical Functions with Formulas, Graphs, and Mathematical Takles, U.S. Department of Commerce, National Bureau of Standards, Applied Mathematics Series, No. 55, 1964

21) Wald, T. H. Heaton, and K. W. Hudnut : The Slip History of the 1994 Northridge, Calfornia, Earthquake Determined From Strong-Motion, Teleseismic, GPS, and Leveling Data, Bull Sesm. Soc. Am., Vol.86, No.1, Part B, 49-70, 1996

22) Press, W. H., S. A. Teukolsky, W. T. Vetterling, and B. R. Flannery: Numerical Recipes in Fortran, 2nd Edition, Cambridge University Press, 1992.

（1997年 1 月 6 日原稿受理，1997年 6 月24日採用決定） 